\title{
worldview
}

A JOURNAL OF RELIGION AND INTERNATIONAL AFFAIRS

\section{THE CLERGY ON VIETNAM: CONCERN FOR THE CONCERNED}

The clergy are showing their concern about Vietnam today, and a number of people are now getting concemed about the clergy. Church leaders have been urged to engage in the immediate problems of our social and political life and now that they have some people are wondering if they're not all too lively.

The experience of the late thirties and early forties has provided lessons for all those who are concerned with international affairs. Secretary of State Rusk insists that the one indelible lesson to be leamed is the folly of appeasing an aggressor whose appetite grows by what it feeds on; many church leaders declare that what the churches have learned is the folly of giving unquestioned support to govemment policy, particularly while that policy is still in its formative stages.

In recent weeks individual religious leaders and organizations have posed, once again, the problem which is destined to have no final solution: what is the responsibility of the religious person and of the churches in international affairs? what are the areas of competence and what the limitations that should be observed? Is there an authentic religious yoice and, if so, how is it recognized? Even within recent weeks the variety of responses to the Vietnam crisis has revealed the discordant answers that these questions do, in fact, provoke.

$+$

Pope Paul has been very forceful in his urgent expressions of peace. Yet at the very time that he suggested United Nations arbitration of the Vietramese conflict he very carefully delineated what he regarded as his proper area of competence. "Judgment of political questions and temporal interest," he said, was not his to make. More recently, the Reverend Dr. W. A. Visser 't Hooft, then Secretary General of the World Council of Churches, defended the right of church bodies to take definite stands on social and political issues, however thorny and complicated. And he mentioned specifically Vietram. He rejected arguments that would inhibit churches from speaking on temporal matters, arguments that would restrict churches to statements of principles with unspecified application, arguments that would question the competence of church groups in political affairs. Dr. Visser 't Hooft said that the churches have a "duty in critical situations with grave moral implications to become specific to the point of indicating in which direction the nation or nations should go."

$\bullet$

It is clear that in this country there are a number of new organizations, united in their religious concems, that are speaking out on Vietnam with religious fervor and political specificity. They are following the path indicated by Dr. Visser 't Hooft. Unfortunately some of these groups-or, more accurately, some individuals within these groups-have not been as self-aware or as self-critical as Dr. Visser 't Hooft who also said the churches had not yet prepared themselves for the crucial role they are called upon to assume, that they were not yet prepared to give specific advice and concrete recommendations to politicians and statesmen.

The danger of itresponsible statements by religiously organized groups in this country is very real. There is a tendency among some religious spokesmen to offer resounding moral pronouncements that have no political resonance. They forget or ignore the harsh truth that, in the face of an historical situation, a moral solution that is not at the same time a political solution is no solution at all.

Yet it would be a clear dereliction of duty if the churches were to offer only silence, conformity or a rubber stamp of present U.S. policy. That duty does not, however, bring with it some won- 
derful measure of political competence or insight that is beyond the professional statesman. What is required of the religiously organized groups that would speak to political matters are: the hard work which alone allows a responsible judgment, an intellectual humility which recognizes that other men may honestly and soberly come to quite different conclusions, and an acceptance of the fact that one's own political judgments and opinions may be quite overridden and discarded by history.

It is, admittedly, difficult to remain constantly aware of such limitations in a crisis as severe as the Vietnam war. Our public debate is, if not a shambles, a disgrace. Congress has not initiated the full-scale debate that the citizenry deserves, analytical TV coverage is at a minimum, and critics of the present U.S. policy are all too read- ily lumped together and dismissed with an unpleasant label. When President Johnson said, on his Honolulu trip, that those who "counsel retreat" from the war "belong to a group that has always been blind to experience and deaf to hope," he displayed both the short-sighted irritation and arrogance that are increasingly common in official statements. But if such statements are countered by equal irritation and moral arrogance on the part of religious groups, the lines of communication between the decision-makers and a substantial part of the citizenry will almost cease to exist. There is a responsibility on the government to understand the needs of an in formed public, but there is an equal responsibility on the part of church leaders to appreciate the problems and pressures that burden the policy makers.

J.F.

\section{in the magaxines}

Rabbi Richard J. Israel, Director of the B'nai B'rith Foundation at Yale, looked for the source of Jewish social values which he could relate to present-day political decisions and actions, and his findings, originally presented in an address to the National Hillel Summer Institute, are reprinted in the January issue of Jewish Frontier.

He comments that for such questions as "what to do about Vietnam, the John Birch Society or urben renewal," neither the Bible nor Jewish Law, the Jew's "marginal status" nor Jewish self-interest provides the exclusive answer or complete guidelines. The only conclusion that he can come to, Rabbi Israel says, is one. "that creates as many problems as it solves. It is, however, the only one available to me, that of personal synthesis: facing the world and attempting to deal with it as best I can as a modern Western man and as a concerned jew. I use the tradition as a check and as a source of social values. It cannot present me with a rule book, much as my personal temperament tells me that I want one. If the tradition doesn't, or can't, tell me explicitly whether I may endorse the use of atomic weapons or nerve gas, there are still ideas that I might be able to find that will give me help so that I am not left altogether to my own devices. Rabbi Seymour
Seigel put ic rather well when he said that we could use the tradition in these areas of social concern as a goad, a guide and a goal: a goad, in that it prods us into caring; a guide, in that it presents us with some limitations and suggested lines of action; a goal, in that it gives us a vision of the ideal future for which we are working."

The Rabbi notes at one point that it is "not surprising that we have no theology of the state that would parallel the literature of the Catholic Church Once, two thousand years ago, we began to develop such a theology; but since we have seldom been close to the sources of power, we have not continued to develop any sort of adequate rationale for dealing with it." Indeed, during much of the past, "the individual Jew had no rights in a given place. The Jewish conmunity had a number of privileges which were granted directly by the reigning mouarch and in which individual Jews participated" Always "governments were viewed as frail, temporary structures which could not be relied upon. Not only were they not very stable, empirically, theologically they were trivial as well. No institution that was not divinely authorked in the Torah could make any truly serious claim upon the Jew. Furthermore, all governments would be overturned at the coming of the Messiah.

\section{2 worldviewo}

